\title{
Bisphenol A Modifies the Regulation Exerted by Testosterone on $5 \alpha$-Reductase Isozymes in Ventral Prostate of Adult Rats
}

\author{
Pilar Sánchez, ${ }^{1}$ Beatriz Castro, ${ }^{1}$ Jesús M. Torres, ${ }^{1,2}$ Asunción Olmo, ${ }^{3}$ \\ Raimundo G. del Moral, ${ }^{3}$ and Esperanza Ortega ${ }^{1,2}$ \\ ${ }^{1}$ Department of Biochemistry and Molecular Biology, Faculty of Medicine, University of Granada, Avenida de Madrid $s / n$, \\ 18012 Granada, Spain \\ ${ }^{2}$ Institute of Neurosciences, Faculty of Medicine, University of Granada, 18012 Granada, Spain \\ ${ }^{3}$ Department of Pathology, San Cecilio University Hospital and School of Medicine, University of Granada, 18012 Granada, Spain
}

Correspondence should be addressed to Jesús M. Torres; torrespi@ugr.es and Esperanza Ortega; esortega@ugr.es

Received 30 April 2013; Revised 20 June 2013; Accepted 6 July 2013

Academic Editor: S. L. Mowbray

Copyright (C) 2013 Pilar Sánchez et al. This is an open access article distributed under the Creative Commons Attribution License, which permits unrestricted use, distribution, and reproduction in any medium, provided the original work is properly cited.

\begin{abstract}
The development, growth, and function of the prostate gland depend on androgen stimulation. The primary androgen in prostate is $5 \alpha$-dihydrotestosterone (DHT) which is synthesized from circulating testosterone (T) through the action of $5 \alpha$-reductase $(5 \alpha$ $\mathrm{R})$. Although $5 \alpha$-R occurs as five isozymes, only $5 \alpha$-R1 and $5 \alpha-\mathrm{R} 2$ are physiologically involved in steroidogenesis. The endocrine disruptor bisphenol A (BPA) alters sexual organs, including the prostate. Our previous findings indicated that BPA decreased the expression of $5 \alpha-\mathrm{R} 1$ and $5 \alpha-\mathrm{R} 2$ in rat prostate but also circulating T. Thus, it is unclear whether BPA exerts this effect on $5 \alpha$-R isozymes by reducing circulating T or by any other mechanism. In this study, we examine the effects of short-term exposure to BPA at doses below $25 \mu \mathrm{g} / \mathrm{Kg} / \mathrm{d}$ and above $300 \mu \mathrm{g} / \mathrm{Kg} / \mathrm{d}$ of the TDI on mRNA levels of $5 \alpha$-R1 and $5 \alpha$-R2 in prostate of adult castrated rats supplemented with $\mathrm{T}$ to achieve constant circulating $\mathrm{T}$ levels. mRNA levels were measured by absolute quantitative RT-PCR, T levels by RIA, and DHT levels by ELISA. Our results indicated that in castrated rats treated with T BPA at the two doses studied significantly decreased the mRNA levels of both $5 \alpha$-R isozymes in a dose-dependent manner without modifications in circulating T.
\end{abstract}

\section{Introduction}

The prostate plays a key role in the reproductive mechanism of a man. The prostate is a secretory gland surrounding the urethra at the base of the bladder. As part of the male reproductive system, the prostate gland's primary function is to secrete nutrients, ions, proteins, and hormones that are added to the ejaculatory fluid produced by the seminal vesicles. These molecules are necessary for the survival of the spermatozoids during their journey through the female reproductive tract.

Androgens play a critical role in normal prostatic growth, development, and maintenance throughout the lifespan [1]. Likewise, androgen deprivation at any stage of life causes a decrease in prostate cell number and DNA content [2]. The most potent androgen in the prostate is $5 \alpha$ dihydrotestosterone (DHT) with 10-fold higher potency to induce androgen receptor (AR) signaling than testosterone (T) [3]. DHT is synthesized from circulating $\mathrm{T}$ by the enzyme steroid $5 \alpha$-reductase $(5 \alpha-\mathrm{R}$, EC 1.3.99.5). Of the five types of $5 \alpha$-R enzymes characterized to date, only type 1 ( $5 \alpha-$ R1) and type $2(5 \alpha-\mathrm{R} 2)$ are believed to be physiologically involved in steroidogenesis [4]. $5 \alpha$-R1 isozyme occurs in tissues such as the liver [5], the skin, and the brain, where it acts as a key enzyme in the biosynthesis of neuroactive steroids [6-9], although it is also expressed in the prostate $[10,11] .5 \alpha-\mathrm{R} 2$ isozyme is predominantly expressed in male reproductive tissues including the prostate [10-13]. Normal growth, development, and function of the prostate are mainly regulated by $5 \alpha-\mathrm{R} 2$, with $5 \alpha-\mathrm{R} 1$ also contributing to these events $[10,14,15]$.

A wide range of environmental and industrial chemicals can disrupt growth, development, and normal function of the prostate by interfering with the physiological action of 
both androgens and estrogens. Bisphenol A (BPA) is an environmental endocrine disruptor which has been shown to mimic the estrogenic action [16] and may also modify the androgenic action $[17,18]$. BPA is used extensively in the production of polycarbonate plastics, epoxy linings of food and beverage cans, and in dental products $[19,20]$. Exposure to BPA is nearly universal. In a recent study, BPA was detected in urine samples from $92.6 \%$ of the US population examined [21].

Our research group has recently demonstrated that the short-term administration of BPA to adult rats is associated with a decrease in the expression of both $5 \alpha$-R1 and $5 \alpha$ $\mathrm{R} 2$ isozymes [22]. The change in $5 \alpha$ - $\mathrm{R}$ isozymes levels may cause subsequent prostate dysfunction by interfering with androgens metabolism. We also found decreased plasma $\mathrm{T}$ levels in BPA-treated rats. Our previous study showed that $5 \alpha-\mathrm{R} 1$ and $5 \alpha-\mathrm{R} 2$ are positively regulated by $\mathrm{T}$ within the prostate [10]. Therefore BPA may exert its downregulating effects on $5 \alpha-\mathrm{R}$ isozymes by reducing $\mathrm{T}$ levels or by other mechanisms.

In order to shed light on this question, in this study we have examined the effects of short-term BPA exposure on the expression of $5 \alpha-\mathrm{R} 1$ and $5 \alpha-\mathrm{R} 2$ isozymes in ventral prostate of adult castrated rats supplemented with constant doses of $\mathrm{T}$.

\section{Materials and Methods}

2.1. Animals and Treatments. Experiments were performed strictly in accordance with recommendations in the Guide for the Care and Use of Laboratory Animals of the National Institutes of Health. Animal care and experimental procedures were approved by the Animal Experimentation Ethics Committee of the University of Granada, Spain (Ref. 4122012).

Adult male Wistar rats weighing 260-280 g were housed in an air-conditioned room with fluorescent lights on from 08:00 to 20:00 and given standard laboratory pellet chow (Panlab rodent chow, Barcelona, Spain). Although the concentration of phytoestrogens in the diet was not evaluated, all animals were exposed to the same phytoestrogen levels because the food intake was equivalent for BPA-treated and nontreated rats. Exposure to environmental endocrine disruptors was minimized by housing the rats in stainless steel cages and using glass bottles with rubber stoppers to supply them with tap water. The experimental groups studied were castrated rats $(C)$, castrated rats plus $\mathrm{T}(\mathrm{C}+\mathrm{T})$, castrated rats plus $\mathrm{T}$ plus BPA $(25 \mu \mathrm{g} / \mathrm{Kg} / \mathrm{d})(\mathrm{C}+\mathrm{T}+\mathrm{BPA} 25)$, and castrated rats plus $\mathrm{T}$ plus $\mathrm{BPA}(300 \mu \mathrm{g} / \mathrm{Kg} / \mathrm{d})(\mathrm{C}+\mathrm{T}$ + BPA300). All animals underwent bilateral orchidectomy under ether anesthesia. A week later, with the exception of group C, all rats were subcutaneously (s.c.) daily injected with $500 \mu \mathrm{g}$ of testosterone propionate (Sigma-Aldrich, St. Louis, MO, USA) dissolved in sesame oil vehicle for four days. $30 \mathrm{~min}$ before the administration of $\mathrm{T}$, the rats grouped in $\mathrm{C}+\mathrm{T}+\mathrm{BPA} 25$ and $\mathrm{C}+\mathrm{T}+$ BPA300 were s.c. daily injected with BPA (Sigma-Aldrich, St. Louis, MO, USA) dissolved in sesame oil vehicle at doses of $25 \mu \mathrm{g} / \mathrm{Kg} / \mathrm{d}$ and $300 \mu \mathrm{g} / \mathrm{Kg} / \mathrm{d}$, respectively, for four days. Group C was s.c. daily injected with oil vehicle alone. We have followed the protocol of Leranth et al. [23], but we have also administered BPA at dose of $25 \mu \mathrm{g} / \mathrm{Kg} / \mathrm{d}$ in order to study the effects of BPA at doses under the Tolerable Daily Intake $(50 \mu \mathrm{g} / \mathrm{Kg} / \mathrm{d})$. 30 min after the last injection of $\mathrm{T}$, rats were euthanized by decapitation, and the prostate was removed, weighed, frozen in liquid nitrogen, and stored at $-80^{\circ} \mathrm{C}$ until analysis. Blood samples were collected in heparinized tubes. The blood was centrifuged at $2000 \mathrm{rpm}$ for $10 \mathrm{~min}$. The plasma was separated and stored at $-20^{\circ} \mathrm{C}$ until the hormone analysis. Each study group comprised 8 animals.

2.2. Hormone Assays. Plasma $\mathrm{T}$ concentrations were measured by RIA using a commercial (DiaSorin Vercelli, Italy) kit without modifications; intra- and interassay coefficients of variation were $7.6 \%$ and $12.0 \%$, respectively, and the sensitivity was $0.05 \mathrm{ng} / \mathrm{mL}$. Plasma DHT concentrations were measured by direct ELISA using a commercial (Diagnostics Biochem Canada, Inc., Ontario, Canada) kit; intra- and inter-assay coefficients of variation were $5.9 \%$ and $7.5 \%$, respectively, and the sensitivity was $6.0 \mathrm{pg} / \mathrm{mL}$.

2.3. RNA Extraction and Reverse Transcription. Total RNA was extracted from $50 \mathrm{mg}$ of rat ventral prostate tissue with Trizol reagent (Invitrogen) according to the instructions of the Sanger Institute. RNA samples were then treated with Turbo-DNAse (Ambion) to remove any contamination with genomic DNA. The quantity and purity were determined by using a NanoDrop ND-1000 spectrophotometer (A260/280 ratio), and the integrity was tested by means of denaturing gel electrophoresis. First-strand cDNA was synthesized from $1 \mu \mathrm{g}$ of total RNA by using MuLV reverse transcriptase (Applied Biosystems). The following agents were added to a final volume of $20 \mu \mathrm{L}$ reaction: $5 \mathrm{mM} \mathrm{MgCl}_{2}, 1 \times \mathrm{RT}$ buffer, $1 \mathrm{mM}$ each dNTP, $1 \mathrm{U} / \mu \mathrm{L}$ RNase inhibitor, $2.5 \mathrm{U} / \mu \mathrm{L} \mathrm{MuLV}$ reverse transcriptase, $2.5 \mu \mathrm{M}$ Oligo $(\mathrm{dT})_{16}$, and $1 \mu \mathrm{g}$ total RNA. Reactions were incubated at $42^{\circ} \mathrm{C}$ for $15 \mathrm{~min}$, followed by $5 \mathrm{~min}$ at $99^{\circ} \mathrm{C}$.

2.4. Quantitative Real-Time PCR. Absolute quantification of mRNA levels of $5 \alpha-\mathrm{R} 1$ and $5 \alpha-\mathrm{R} 2$ in rat prostate tissues was performed by real-time PCR using the Techne Quantica real-time PCR system with SYBR Green PCR Master Mix (Promega). In comparison to relative quantification, this method offers the advantage of giving an absolute copy number for a specific target. The amount of mRNA was expressed as the number of mRNA copies per micrograms of total RNA. We amplified tissue samples by real-time PCR in parallel with competitive cRNA standard curves generated following the method described by Fronhoffs et al. [24].

The PCR profile was as follows: denaturation at $94^{\circ} \mathrm{C}$ for 30 seconds, annealing at $55^{\circ} \mathrm{C}$ for 30 seconds, and extension at $72^{\circ} \mathrm{C}$ for 30 seconds. The number of cycles was 40 in all cases. At the end of the amplification phase, a melting curve analysis was carried out on the products formed in order to confirm that a single PCR product was detected by the SYBR Green dye. 
TABle 1: Primer sequences $\left(5^{\prime}-3^{\prime}\right)$ for PCR amplification.

\begin{tabular}{lll}
\hline Primers & Forward primer & Reverse primer \\
\hline $5 \alpha-\mathrm{R} 1$ & GAGATATTCAGCTGAGACCC & TTAGTATGTGGGCAGCTTGG \\
$5 \alpha-\mathrm{R} 2$ & ATTTGTGTGGCAGAGAGAGG & TTGATTGACTGCCTGGATGG \\
\hline
\end{tabular}

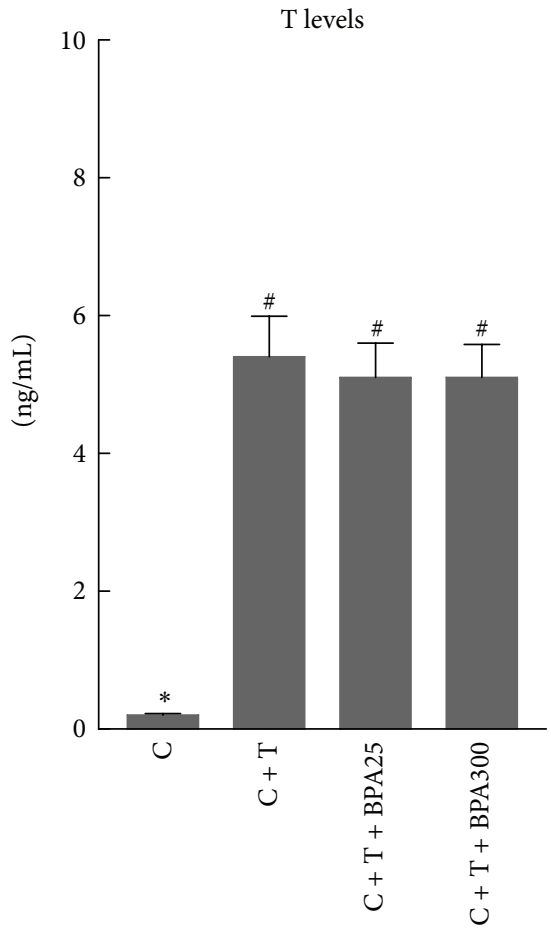

(a)

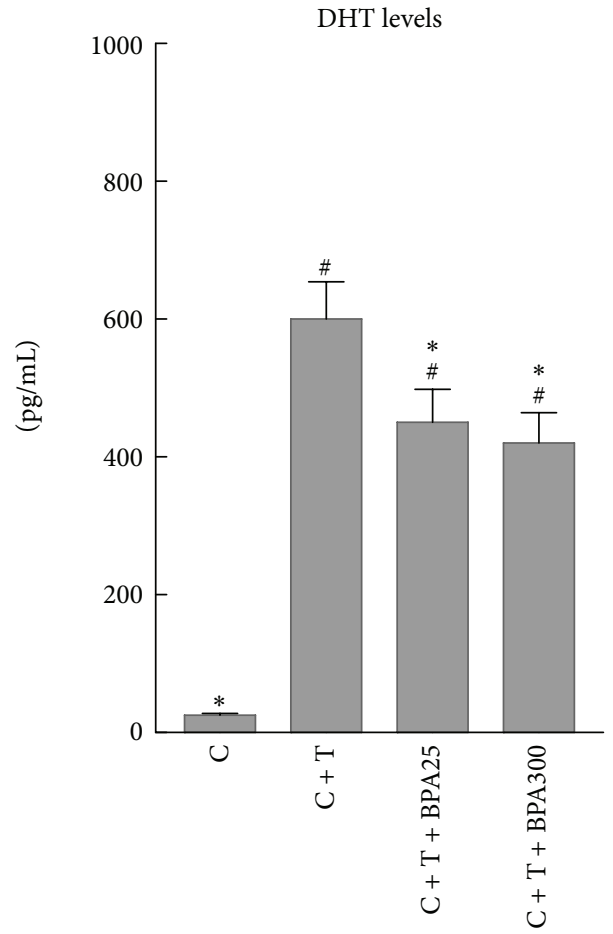

(b)

FIGURE 1: Plasma testosterone (T) levels (a) and plasma dihydrotestosterone (DHT) levels (b) in castrated rats (C), castrated rats supplemented with $\mathrm{T}(\mathrm{C}+\mathrm{T})$, and castrated rats supplemented with $\mathrm{T}$ plus BPA at doses of $25 \mu \mathrm{g} / \mathrm{Kg} / \mathrm{d}(\mathrm{C}+\mathrm{T}+\mathrm{BPA} 25)$ and $300 \mu \mathrm{g} / \mathrm{Kg} / \mathrm{d}(\mathrm{C}+\mathrm{T}+\mathrm{BPA} 300)$ for 4 days. ${ }^{\#} P<0.05$ or less versus $\mathrm{C}$ group. ${ }^{*} \mathrm{P}<0.05$ or less versus $\mathrm{C}+\mathrm{T}$ group.

Primers for $5 \alpha$-R1 (Srd5a1 mRNA, Genbank accession $\mathrm{n}^{\circ}$ NM_017070.3) and 5 $\alpha$-R2 (Srd5a2 mRNA, Genbank accession $n^{\circ}$ NM_022711.4) were designed using Primer 3 software. The primer sequences $\left(5^{\prime}-3^{\prime}\right)$ are given in Table 1 .

2.5. Statistical Analysis. Statistical analysis of the results was performed using the Student's $t$-test. Data are expressed as mean $\pm \mathrm{SD}$. The statistical analysis was performed using the STATA Version 10 (Stata Corp. 2007) software.

\section{Results}

3.1. Plasma T and DHT Levels. Castrated animals had lower $\mathrm{T}$ levels. All groups treated with $\mathrm{T}$ had a significant increase in plasma $\mathrm{T}$ levels in comparison with castrated rats without $\mathrm{T}$ treatment (Figure 1(a)). Both groups treated with BPA at the doses of $25 \mu \mathrm{g} / \mathrm{Kg} / \mathrm{d}$ and $300 \mu \mathrm{g} / \mathrm{Kg} / \mathrm{d}$ had similar plasma $\mathrm{T}$ levels, with no significant differences in comparison with T-treated castrated rats (Figure 1(a)). Castrated animals had lower DHT levels. All groups treated with T had a significant increase in plasma DHT levels in comparison with castrated rats without $\mathrm{T}$ treatment (Figure $1(\mathrm{~b})$ ). Both groups treated with BPA at the doses of $25 \mu \mathrm{g} / \mathrm{Kg} / \mathrm{d}$ and $300 \mu \mathrm{g} / \mathrm{Kg} / \mathrm{d}$ had lower plasma DHT levels, in comparison with T-treated castrated rats, with no significant differences between both BPA-treated groups (Figure 1(b))

3.2. $5 \alpha-R 1$ and $5 \alpha-R 2 m R N A$ Levels. All groups treated with $\mathrm{T}$ had a significant increase in $5 \alpha$-R1 mRNA levels in comparison with castrated rats without $\mathrm{T}$ treatment (Figure 2(a)). Both groups treated with BPA at the doses of $25 \mu \mathrm{g} / \mathrm{Kg} / \mathrm{d}$ and $300 \mu \mathrm{g} / \mathrm{Kg} / \mathrm{d}$ had significant decreased $5 \alpha$-R1 mRNA levels in comparison with castrated rats treated with T (Figure 2(a)). In addition, BPA-treated rats at dose of $300 \mu \mathrm{g} / \mathrm{Kg} / \mathrm{d}$ had significant decreased $5 \alpha$-R1 mRNA levels when compared with BPA-treated rats at dose of $25 \mu \mathrm{g} / \mathrm{Kg} / \mathrm{d}$ (Figure 2(a)).

All groups treated with Thad a significant increase in $5 \alpha$ R2 mRNA levels in comparison with castrated rats without $\mathrm{T}$ treatment (Figure 2(b)). Both groups treated with BPA at the doses of $25 \mu \mathrm{g} / \mathrm{Kg} / \mathrm{d}$ and $300 \mu \mathrm{g} / \mathrm{Kg} / \mathrm{d}$ had significant decreased $5 \alpha-\mathrm{R} 2$ mRNA levels in comparison with castrated rats treated with $\mathrm{T}$ (Figure $2(\mathrm{~b})$ ). In addition, BPA-treated rats at dose of $300 \mu \mathrm{g} / \mathrm{Kg} / \mathrm{d}$ had significant decreased $5 \alpha$-R2 


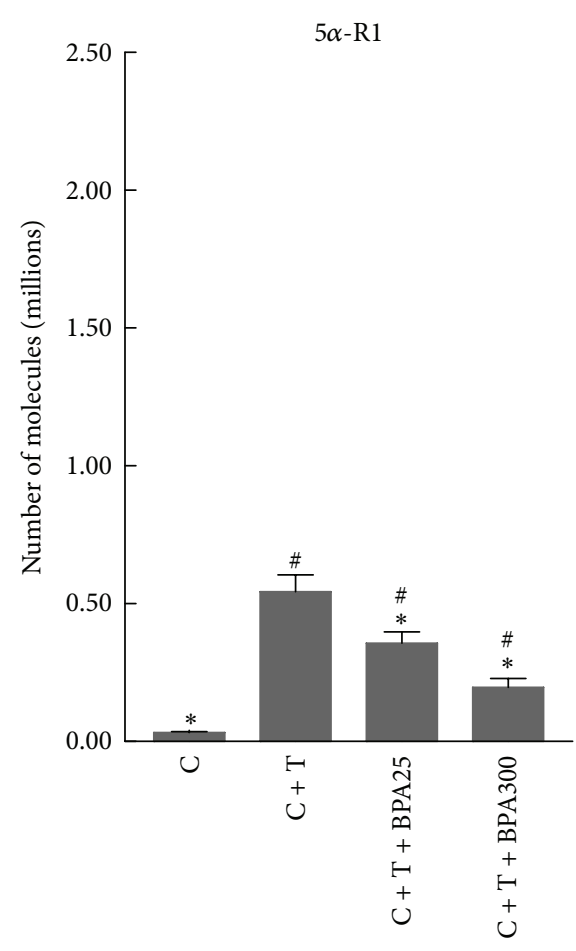

(a)

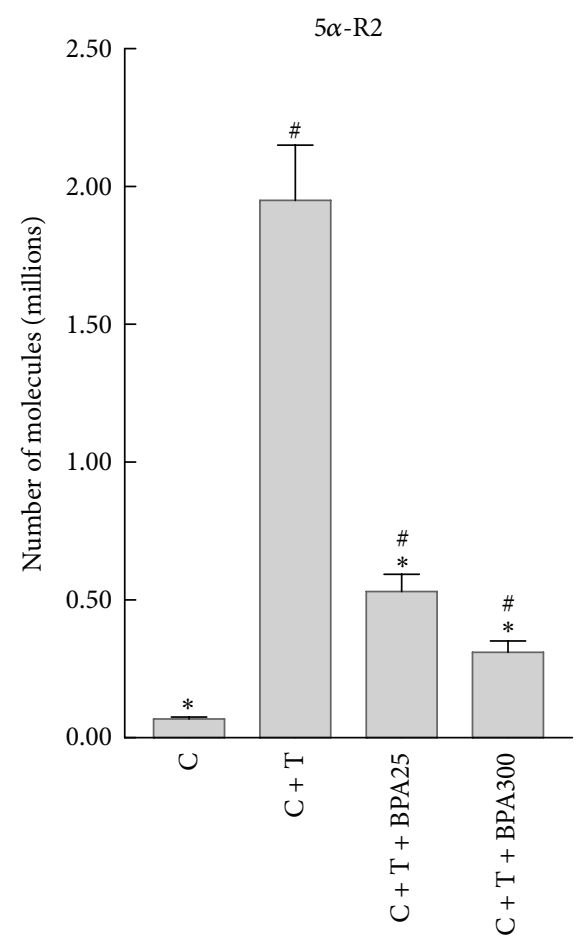

(b)

FiguRE 2: mRNA levels of $5 \alpha$-R1 (a) and $5 \alpha-\mathrm{R} 2$ (b) in prostate of castrated rats (C), castrated rats supplemented with $\mathrm{T}(\mathrm{C}+\mathrm{T})$, and castrated rats supplemented with $\mathrm{T}$ plus BPA at doses of $25 \mu \mathrm{g} / \mathrm{Kg} / \mathrm{d}(\mathrm{C}+\mathrm{T}+\mathrm{BPA} 25)$ and $300 \mu \mathrm{g} / \mathrm{Kg} / \mathrm{d}(\mathrm{C}+\mathrm{T}+\mathrm{BPA} 300)$ for 4 days. ${ }^{\#} P<0.05$ or less versus $\mathrm{C}$ group. ${ }^{*} \mathrm{P}<0.05$ or less versus $\mathrm{C}+\mathrm{T}$ group.

mRNA levels when compared with BPA-treated rats at dose of $25 \mu \mathrm{g} / \mathrm{Kg} / \mathrm{d}$ (Figure 2(b)).

BPA produced a much greater reduction on $5 \alpha-\mathrm{R} 2(P<$ $0.01)$ than that observed for $5 \alpha-\mathrm{R} 1(P<0.05)$ mRNA levels.

3.3. Prostate Weight. All groups treated with $\mathrm{T}$ had a significant increase in prostate weight in comparison with castrated rats without $\mathrm{T}$ treatment (Figure 3 ). Both groups treated with $\mathrm{BPA}$ at the doses of $25 \mu \mathrm{g} / \mathrm{Kg} / \mathrm{d}$ and $300 \mu \mathrm{g} / \mathrm{Kg} / \mathrm{d}$ had similar prostate weight, with no significant differences in comparison with T-treated castrated rats (Figure 3 ).

\section{Discussion}

The normal development and function of the adult prostate are dependent on the action of DHT, which is synthesized within the prostate from circulating T by the enzyme $5 \alpha$ $\mathrm{R}$. Of the five types of $5 \alpha$-R enzymes characterized to date, only $5 \alpha-\mathrm{R} 1$ and $5 \alpha-\mathrm{R} 2$ are believed to be physiologically involved in steroidogenesis [25]. $5 \alpha$-R1 and $5 \alpha$-R2 are mainly expressed in epithelial and stromal cells, respectively [26]. In epithelial cells, $5 \alpha$-R1 isozyme may be responsible for synthesizing DHT, which acts in an autocrine manner to stimulate their differentiation. Alternatively, DHT may act in paracrine fashion to stabilize or stimulate the division of the adjacent androgen-dependent luminal epithelium [26].
Expression of $5 \alpha-\mathrm{R} 2$ isozyme in the stroma of the prostate is consistent with the central role played by these cells in the development of the gland [26]. Given the important role that both isozymes play in the prostate function, several factors are responsible for the Srd5a1 and Srd5a2 gene regulation, including $\mathrm{T}$ as we previously demonstrated [10].

The results of the present study show that the administration of $\mathrm{T}$ for four days exerts an upregulation of both $5 \alpha$-R1 and $5 \alpha$-R2 isozymes, with this effect being greater for $5 \alpha-\mathrm{R} 2$. Our group previously reported that both $5 \alpha$-R isozymes were positively regulated by $\mathrm{T}$ [10]. However, in this study we have used a different $\mathrm{T}$ dose, a different injection schedule, and a more accurate technology to quantify the mRNA levels. We previously quantified $5 \alpha-\mathrm{R}$ isozymes mRNA levels by competitive RT-PCR coupled with laser-induced fluorescence capillary electrophoresis (LIF-CE) using a mimic DNA as internal standard [27]. However, this method appears to have some drawbacks which may impair the efficiency of PCR amplification, that is, different size and nucleotide sequence between target cDNA and competitive standard DNA and the fact that $\mathrm{CDNA}$ obtained from $\mathrm{RT}$ reaction is a mixed RNA/DNA molecule while competitive standard is added in DNA form. We have now circumvented these limitations by using another approach for the accurate measurement of gene transcript levels, which is based on real-time PCR in combination with a rapid and simple method for the construction of simultaneously amplified cRNA standard 


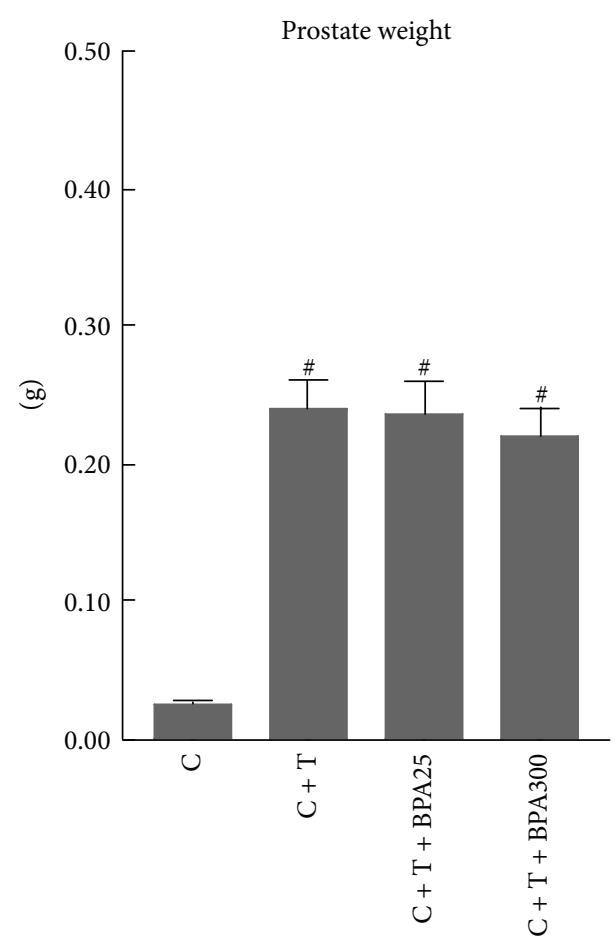

FIGURE 3: Prostate weight of castrated rats (C), castrated rats supplemented with $\mathrm{T}(\mathrm{C}+\mathrm{T})$, and castrated rats supplemented with T plus BPA at doses of $25 \mu \mathrm{g} / \mathrm{Kg} / \mathrm{d}(\mathrm{C}+\mathrm{T}+\mathrm{BPA} 25)$ and $300 \mu \mathrm{g} / \mathrm{Kg} / \mathrm{d}$ $(\mathrm{C}+\mathrm{T}+\mathrm{BPA} 300)$ for 4 days. ${ }^{\sharp} P<0.05$ or less versus $\mathrm{C}$ group.

curves with identical size and nucleotide sequences as the target gene [24].

According to the present results, short-term BPA administration to castrated rats supplemented with $\mathrm{T}$ decreased the mRNA levels of both $5 \alpha$-R1 and $5 \alpha$-R2 isozymes in ventral prostate of rats, which had constant levels of circulating $\mathrm{T}$. BPA has been shown to exert endocrine-disrupting effects on reproduction, development, and metabolism [28]. Recent findings linked exposure to BPA with several male reproductive disorders [29-32] and prostate diseases [33, 34]. Our group recently demonstrated that adult exposure to BPA decreased in the rat prostate gland the expression of both $5 \alpha$ $\mathrm{R} 1$ and $5 \alpha-\mathrm{R} 2$, as well as the circulating T levels [22]. The latter finding is not surprising to us since BPA decreases luteinizing hormone (LH) secretion [35] and inhibits T biosynthetic enzymes in the testis [36]. Because within the prostate $5 \alpha$ $\mathrm{R} 1$ and $5 \alpha-\mathrm{R} 2$ are positively regulated by T [10], BPA may downregulate both $5 \alpha$-R isozymes by decreasing T levels, but in our study the circulating levels of $\mathrm{T}$ were constant. A possible explanation to this fact may be the circulating levels of DHT which are decreased in our BPA-treated rats. In this context, the effects of BPA on other tissues where $5 \alpha$ reduction occurs such as liver and skin should be also kept in mind to explain the diminished circulating DHT levels. Our previous finding showed that DHT exerts a positive effect on the genetic expression of both $5 \alpha$-R isozymes in the prostate, although with a lesser extent than that observed for $\mathrm{T}$ [10]. In vitro studies reveal that when DHT formation is inhibited it will induce a pronounced downregulation of androgen receptor (AR) mRNA levels [37], which may lead to the downregulation of $5 \alpha$-R isozymes [22].

Another intriguing possibility is that BPA may directly affect AR function via multiple mechanisms: (1) antagonizing AR signaling, (2) avoiding AR translocation to the nucleus, (3) avoiding AR interaction with its coactivator and its subsequent transactivation [17, 18], and (4) decreasing the number of AR in stromal cells of the rat ventral prostate [38]. As have been indicated by Teng et al. [17], BPA binds to AR and competes with androgen binding at the LBD region of the receptor. Like known androgen antagonists, $\mathrm{BPA}$ is unable to promote the formation of functional AR foci in the nucleus. Thus, BPA binding to AR interferes with nuclear receptor translocation.

In this study, BPA treatment did not alter ventral prostate weight, despite the down-regulation of both $5 \alpha$-R isozymes and presumably lower intraprostatic DHT levels, in view of circulating DHT levels. Two points may explain this fact: other additional factors are contributing to the growth of the prostate, and/or the BPA regime followed in this study is not appropriate to induce observable changes in prostate weight. Other authors have shown that prenatal exposure to low dose of BPA increases prostate size [38-40] and these changes persisted during adulthood. The effects of BPA on prostate weight could be dose dependent [39], but also they could be dependent of the BPA administration schedule and the life stage when the exposure occurs.

\section{Conclusion}

Our results showed that BPA decreases the positive regulatory effect that T exerts on $5 \alpha$-R1 and $5 \alpha-\mathrm{R} 2$ gene regulation in the prostate, at least in part, independently of circulating T. Given the important role of $5 \alpha$-R isozymes in the physiological function of the prostate, the exposure to BPA should be considered harmful for this gland.

\section{Conflict of Interests}

The authors do not have direct financial conflict of interests.

\section{Acknowledgments}

The authors are indebted to M. Quintana for their technical assistance. This study was funded in part by the European Fund of Regional Development (FEDER-BFU2008-05340) and the Andalusian Regional Government (Endocrinology \& Metabolism Group).

\section{References}

[1] W. D. Steers, “ $5 \alpha$-reductase activity in the prostate," Urology, vol. 58 , no. 6, pp. 17-24, 2001.

[2] J. D. Wilson, "The critical role of androgens in prostate development," Endocrinology and Metabolism Clinics of North America, vol. 40, no. 3, pp. 577-590, 2011.

[3] T. Saartok, E. Dahlberg, and J.-A. Gustafsson, "Relative binding affinity of anabolic-androgenic steroids: comparison of 
the binding to the androgen receptors in skeletal muscle and in prostate, as well as to sex hormone-binding globulin," Endocrinology, vol. 114, no. 6, pp. 2100-2106, 1984.

[4] M. P. Castelli, A. Casti, A. Casu et al., "Regional distribution of $5 \alpha$-reductase type 2 in the adult rat brain: an immunohistochemical analysis," Psychoneuroendocrinology, vol. 38, no. 2, pp. 281-293, 2013.

[5] J. M. Torres and E. Ortega, "Precise quantitation of steroid $5 \alpha \lambda \pi \eta \alpha$-reductase type $1 \mathrm{mRNA}$ levels by RT-PCR in female rat liver," Endocrine Research, vol. 30, no. 2, pp. 149-157, 2004.

[6] P. Sánchez, J. M. Torres, R. G. Del Moral, J. De Dios Luna, and E. Ortega, "Steroid $5 \alpha$-reductase in adult rat brain after neonatal testosterone administration," IUBMB Life, vol. 64, no. 1, pp. 8186, 2012.

[7] P. Sánchez, J. M. Torres, A. Olmo, F. O’Valle, and E. Ortega, "Effects of environmental stress on mRNA and protein expression levels of steroid $5 \alpha$-Reductase isozymes in adult rat brain," Hormones and Behavior, vol. 56, no. 3, pp. 348-353, 2009.

[8] J. M. Torres and E. Ortega, "Differential regulation of steroid $5 \alpha$-reductase isozymes expression by androgens in the adult rat brain," FASEB Journal, vol. 17, no. 11, pp. 1428-1433, 2003.

[9] J. M. Torres and E. Ortega, "Steroid $5 \alpha$-reductase isozymes in the adult female rat brain: central role of dihydrotestosterone," Journal of Molecular Endocrinology, vol. 36, no. 2, pp. 239-245, 2006.

[10] J. M. Torres, E. Ruiz, and E. Ortega, "Development of a quantitative RT-PCR method to study $5 \alpha$-reductase mRNA isozymes in rat prostate in different androgen status," Prostate, vol. 56, no. 1, pp. 74-79, 2003.

[11] P. Sánchez, J. M. Torres, B. Castro et al., "Expression of steroid $5 \alpha$-reductaseisozymes in prostate of adult rats after environmental stress," The FEBS Journal, vol. 280, no. 1, pp. 93101, 2013.

[12] K. Normington and D. W. Russell, "Tissue distribution and kinetic characteristics of rat steroid $5 \alpha$-reductase isozymes. Evidence for distinct physiological functions," Journal of Biological Chemistry, vol. 267, no. 27, pp. 19548-19554, 1992.

[13] A. E. Thigpen, R. I. Silver, J. M. Guileyardo, M. L. Casey, J. D. McConnell, and D. W. Russell, "Tissue distribution and ontogeny of steroid $5 \alpha$-reductase isozyme expression," Journal of Clinical Investigation, vol. 92, no. 2, pp. 903-910, 1993.

[14] A. Lunacek, C. Schwentner, J. Oswald et al., "Fetal distribution of $5 \alpha$-reductase 1 and $5 \alpha$-reductase 2 , and their input on human prostate development," Journal of Urology, vol. 178, no. 2, pp. 716-721, 2007.

[15] L. N. Thomas, R. C. Douglas, R. S. Rittmaster, and C. K. L. Too, "Overexpression of $5 \alpha$-reductase type 1 increases sensitivity of prostate cancer cells to low concentrations of testosterone," Prostate, vol. 69, no. 6, pp. 595-602, 2009.

[16] W. Xi, C. K. F. Lee, W. S. B. Yeung et al., "Effect of perinatal and postnatal bisphenol A exposure to the regulatory circuits at the hypothalamus-pituitary-gonadal axis of CD-1 mice," Reproductive Toxicology, vol. 31, no. 4, pp. 409-417, 2011.

[17] C. Teng, B. Goodwin, K. Shockley et al., "Bisphenol A affects androgen receptor function via multiple mechanisms," Chemico-Biological Interactions, vol. 203, no. 3, pp. 556-564, 2013.

[18] H. J. Lee, S. Chattopadhyay, E.-Y. Gong, R. S. Ahn, and K. Lee, "Antiandrogenic effects of bisphenol A and nonylphenol on the function of androgen receptor," Toxicological Sciences, vol. 75, no. 1, pp. 40-46, 2003.
[19] A. Goodson, H. Robin, W. Summerfield, and I. Cooper, "Migration of bisphenol A from can coatings-effects of damage, storage conditions and heating," Food Additives and Contaminants, vol. 21, no. 10, pp. 1015-1026, 2004.

[20] N. Olea, R. Pulgar, P. Pérez et al., "Estrogenicity of resinbased composites and sealants used in dentistry," Environmental Health Perspectives, vol. 104, no. 3, pp. 298-305, 1996.

[21] B. S. Rubin and A. M. Soto, "Bisphenol A: perinatal exposure and body weight," Molecular and Cellular Endocrinology, vol. 304, no. 1-2, pp. 55-62, 2009.

[22] B. Castro, P. Sánchez, J. M. Torres et al., "Bisphenol A exposure during adulthood alters expression of aromatase and $5 \alpha$ reductase isozymes in rat prostate," PLoS ONE, vol. 8, no. 2, Article ID e55905, 2013.

[23] C. Leranth, K. Szigeti-Buck, N. J. MacLusky, and T. Hajszan, "Bisphenol A prevents the synaptogenic response to testosterone in the brain of adult male rats," Endocrinology, vol. 149, no. 3, pp. 988-994, 2008.

[24] S. Fronhoffs, G. Totzke, S. Stier et al., "A method for the rapid construction of cRNA standard curves in quantitative real-time reverse transcription polymerase chain reaction," Molecular and Cellular Probes, vol. 16, no. 2, pp. 99-110, 2002.

[25] M. Bortolato, R. Frau, S. C. Godar et al., "The implication of neuroactive steroids in Tourette syndrome pathogenesis: a role for $5 \alpha$-reductase?" Journal of Neuroendocrinology, 2013.

[26] D. W. Rusell and J. D. Wilson, "Steroid 5 alpha reductase: Two genes/two enzymes," Annual Review Biochemistry, vol. 63, pp. 25-61, 1994.

[27] J. M. Torres and E. Ortega, "Quantitation of mRNA levels of steroid $5 \alpha$-reductase isozymes: a novel method that combines quantitative RT-PCR and capillary electrophoresis," International Journal of Biochemistry and Cell Biology, vol. 36, no. 1, pp. 78-88, 2004.

[28] B. S. Rubin, "Bisphenol A: an endocrine disruptor with widespread exposure and multiple effects," Journal of Steroid Biochemistry and Molecular Biology, vol. 127, no. 1-2, pp. 27-34, 2011.

[29] C. A. Richter, L. S. Birnbaum, F. Farabollini et al., "In vivo effects of bisphenol A in laboratory rodent studies," Reproductive Toxicology, vol. 24, no. 2, pp. 199-224, 2007.

[30] D. M. Walker and A. C. Gore, "Transgenerational neuroendocrine disruption of reproduction," Nature Reviews Endocrinology, vol. 7, no. 4, pp. 197-207, 2011.

[31] T. Takao, W. Nanamiya, I. Nagano, K. Asaba, K. Kawabata, and K. Hashimoto, "Exposure with the environmental estrogen bisphenol A disrupts the male reproductive tract in young mice," Life Sciences, vol. 65, no. 22, pp. 2351-2357, 1999.

[32] K. C. Chitra, C. Latchoumycandane, and P. P. Mathur, "Induction of oxidative stress by bisphenol A in the epididymal sperm of rats," Toxicology, vol. 185, no. 1-2, pp. 119-127, 2003.

[33] S. de Flora, R. T. Micale, S. La Maestra et al., "Upregulation of clusterin in prostate and DNA damage in spermatozoa from bisphenol A-treated rats and formation of DNA adducts in cultured human prostatic cells," Toxicological Sciences, vol. 122, no. 1, pp. 45-51, 2011.

[34] J. A. Taylor, C. A. Richter, R. L. Ruhlen, and F. S. Vom Saal, "Estrogenic environmental chemicals and drugs: mechanisms for effects on the developing male urogenital system," Journal of Steroid Biochemistry and Molecular Biology, vol. 127, no. 1-2, pp. 83-95, 2011. 
[35] B. T. Akingbemi, C. M. Sottas, A. I. Koulova, G. R. Klinefelter, and M. P. Hardy, "Inhibition of testicular steroidogenesis by the xenoestrogen bisphenol a is associated with reduced pituitary luteinizing hormone secretion and decreased steroidogenic enzyme gene expression in rat leydig cells," Endocrinology, vol. 145, no. 2, pp. 592-603, 2004.

[36] L. Ye, B. Zhao, G. Hu, Y. Chu, and R.-S. Ge, "Inhibition of human and rat testicular steroidogenic enzyme activities by bisphenol A," Toxicology Letters, vol. 207, no. 2, pp. 137-142, 2011.

[37] M.-C. Lin, J. Rajfer, R. S. Swerdloff, and N. F. Gonzalez-Cadavid, "Testosterone down-regulates the levels of androgen receptor mRNA in smooth muscle cells from the rat corpora cavernosa via aromatization to estrogens," Journal of Steroid Biochemistry and Molecular Biology, vol. 45, no. 5, pp. 333-343, 1993.

[38] J. G. Ramos, J. Varayoud, C. Sonnenschein, A. M. Soto, M. Muñoz de Toro, and E. H. Luque, "Prenatal exposure to low doses of bisphenol A alters the periductal stroma and glandular cell function in the rat ventral prostate," Biology of Reproduction, vol. 65, no. 4, pp. 1271-1277, 2001.

[39] B. G. Timms, K. L. Howdeshell, L. Barton, S. Bradley, C. A. Richter, and F. S. Vom Saal, "Estrogenic chemicals in plastic and oral contraceptives disrupt development of the fetal mouse prostate and urethra," Proceedings of the National Academy of Sciences of the United States of America, vol. 102, no. 19, pp. 70147019, 2005.

[40] G. S. Prins, W.-Y. Tang, J. Belmonte, and S.-M. Ho, "Perinatal exposure to oestradiol and bisphenol A alters the prostate epigenome and increases susceptibility to carcinogenesis," Basic and Clinical Pharmacology and Toxicology, vol. 102, no. 2, pp. 134-138, 2008. 

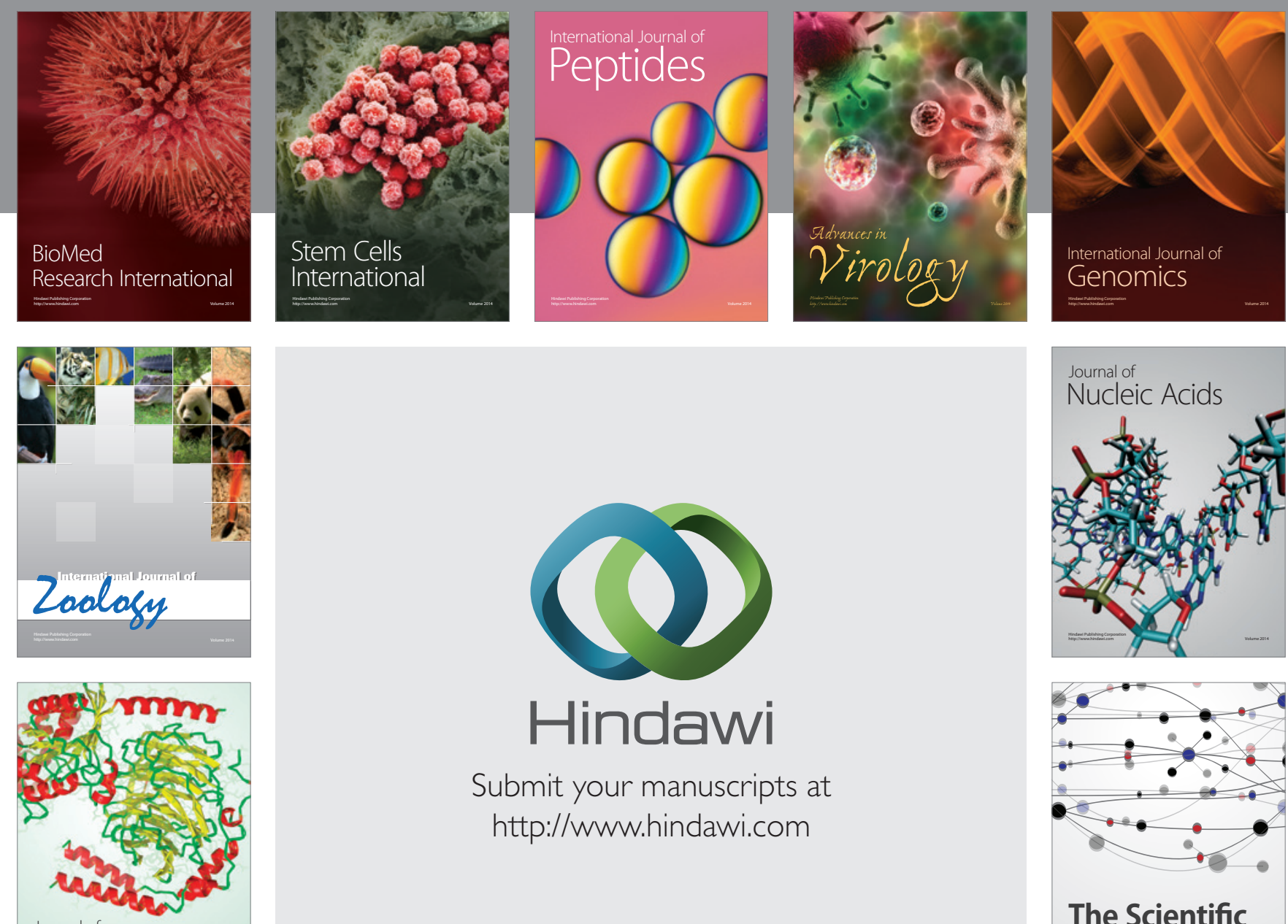

Submit your manuscripts at

http://www.hindawi.com

Journal of
Signal Transduction
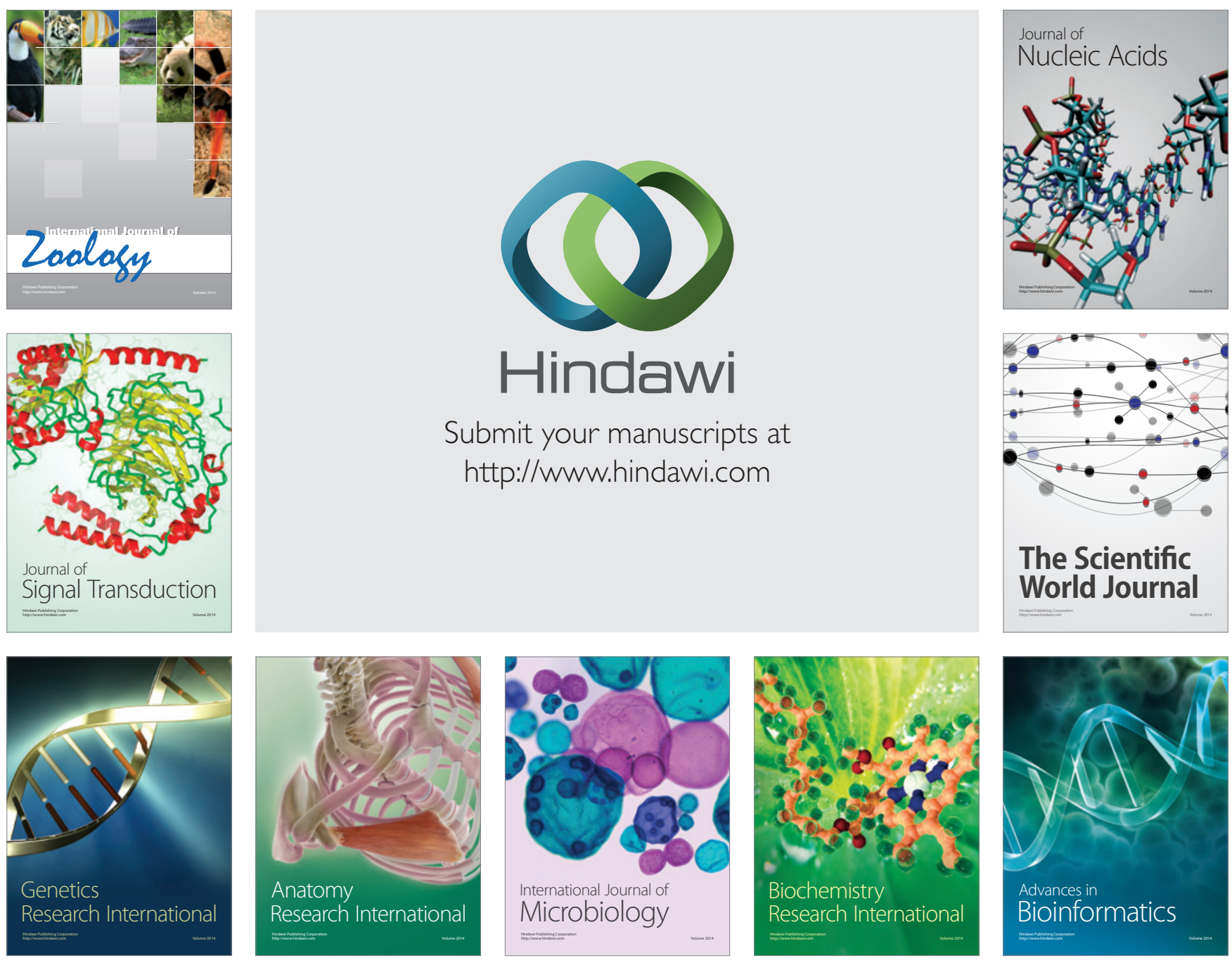

The Scientific World Journal
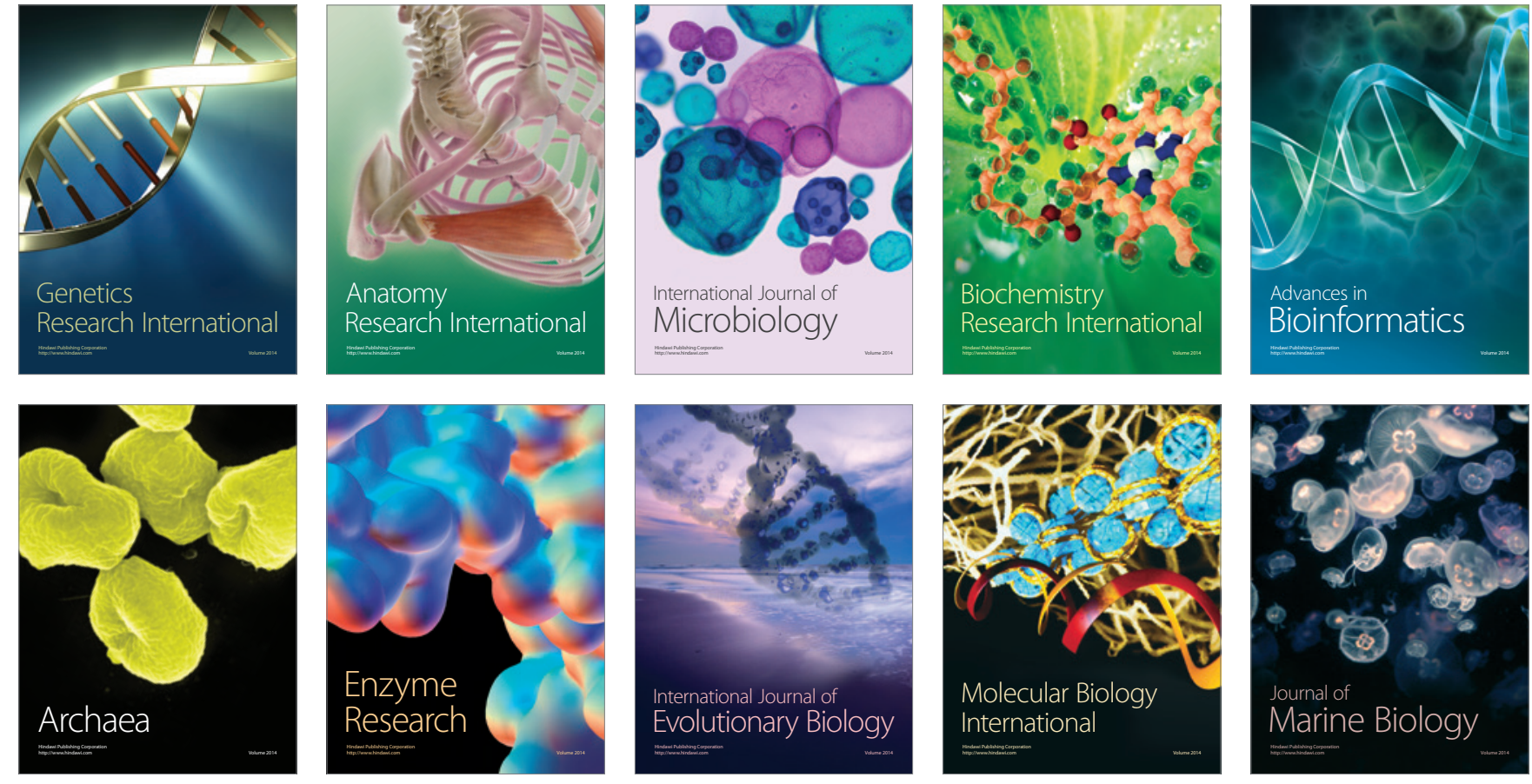